\title{
Anthropological Theory and Government Policy in Australia's Northern Territory: The Hegemony of the "Mainstream"
}

\section{Frances Morphy and Howard Morphy}

\begin{abstract}
In this article, we set up a dialogue between two theoretical frameworks for understanding the developing relationships between indigenous Australians and the encapsulating Australian society. We argue that the concept of "the intercultural" de-emphasizes the agency of Aboriginal people and the durability of their social relations and value orientations. We develop the concept of relative autonomy in apposition. Our primary focus is on the Yolngu people of eastern Arnhem Land and on the impact that recent Australian government policy-in particular the Northern Territory "Intervention" — has had on the relatively autonomous trajectory of their society. The view from relative autonomy enables an understanding of the history of Yolngu interaction with outsiders and Yolngu responses to government policy. We argue that unless relative autonomy is understood and taken into account, governments will fail to develop policies that engage Yolngu in the process of regional development. [relative autonomy, the intercultural, Australian Aborigines, Northern Territory Emergency Response (NTER), indigenous communities and the state]
\end{abstract}

RESUMEN En este artículo, establecemos un diálogo entre dos marcos teóricos para entender las relaciones que se están desarrollando entre indígenas australianos y la sociedad australiana que los rodea. Argumentamos que el concepto de "lo intercultural" le resta énfasis a la agencia de los aborígenes, la durabilidad de sus relaciones sociales y la orientación de sus valores. Adicionalmente, desarrollamos el concepto de autonomía relativa. Nuestro foco inicial es en los Yolngu de la tierra oriental de Arnhem y el impacto que recientes políticas gubernamentales australianasen particular la intervención en el territorio norte-han tenido en la trayectoria relativamente autónoma de su sociedad. La perspectiva de la autonomía relativa permite entender la historia de la interacción de los Yolngu con personas externas y sus respuestas a las políticas gubernamentales. Proponemos que a menos que el concepto de autonomía relativa sea entendido y tenido en cuenta, los gobiernos no lograrán desarrollar políticas con la participación de los Yolngu en el proceso de desarrollo regional. [autonomía relativa, lo intercultural, Aborígenes Australianos, Respuesta de Emergencia en el Territorio del Norte, comunidades indígenas y el estado]

RESUME Dans cet article, nous proposons d'établir un dialogue entre deux cadres théoriques afin de mieux comprendre l'évolution des relations entre les autochtones australiens et la société australienne enfermante. Nous affirmons que le concept de l'interculturalité minimise le pouvoir d'autodétermination du peuple aborigène et la durabilité de leurs relations sociales et leurs valeurs. Nous proposons de juxtaposer le concept d'autonomie relative. Nous explorons l'impact de la politique "d'Intervention" implantée dans le Territoire du Nord sur comment elle a 
affecté les Yolngu de la Terre d'Arnhem et la trajectoire de leur autonomie relative. Comprendre le problème du point de vue de l'autonomie relative nous permet de comprendre I'histoire des relations entre les Yolngu et les non-autochtones ainsi que comment les Yolngu ont affronté la politique gouvernementale. Nous montrons qu'à moins de comprendre ce qu'est l'autonomie relative, les gouvernements vont continuer d'élaborer des politiques incapables d'engager les Yolngu dans un processus de développement régional. [autonomie relative, l'interculturel, Aborigenes Australiens, L'intervention D'urgence de Territoire du Nord, communautés autochtones et l'état]

\begin{abstract}
We are not nothing, we got something there-paintings. ... The paintings are telling us the spiritual way of living, spiritual way to live and survive on the land. But now it's a new generation putting up to tell this world-it's been started a long time since the 1970 s since the church panels at Yirrkala ... my grandfathers done that, they make dhukarr [path] for us ...
\end{abstract}

And we still maintain that culture, still continuing, we are still sharing that culture to other parts of the world, and we are still converting each other .... we are learning from you and you are learning from us. ... We are still searching for what is the best way to live and survive, what is the best way to develop ourselves in our own country, on our own stage. The reason I want to say like that is because I am from homeland and I am also a ranger from the IPA, the Indigenous Protected Area, I work for ranger and that is why I need to manage the Yolngu way and also the modern way - we are putting together so that we can balance the white-man's society and Yolngu society ... we are still learning, because we are living in technology now, we can see the new changes round this world, but we can go through that. We can see the new journey. But the culture, don't forget the country, the land, the djalkiri [foundation], where the songlines start, where the stories are, where the ancestors, that is the important, thank you.

$\mathrm{T}$ his is an extract from a speech by Yinimala $\mathrm{Gu}-$ mana, a Yolngu man in his late twenties from the community of Gängan in northeast Arnhem Land in the Northern Territory of Australia (the full speech, recorded on September 7, 2011, may be viewed at http://www. youtube. com/watch? $=2 \mathrm{Ni} 5 \mathrm{rACaDxA}) . \mathrm{He}$ was speaking during a gallery talk following the presentation of the 2011 Western Australia Indigenous Arts Award. The winner of the $\mathrm{A} \$ 50,000$ prize was Gunybi Ganambarr, his classificatory mother's brother, who also lives at Gängan. Yinimala is Gunybi's djunggayi, which is loosely translatable as the "manager" of one's mother's clan's madayin (ceremonial law). Yinimala had also accompanied Gunybi to the stage when he received his award, an example of one of the small ways in which Yolngu routinely modify the proceedings of public events in non-Yolngu frames according to their own protocols, often to the confusion of non-Yolngu audiences. At the award ceremony, many in the audience were confused about which of the Yolngu men was actually the prize winner (this was evident when people came up afterward to congratulate Yinimala, assuming him to be the artist). However, we summarize his speech here not because of why he spoke but because of what he chose to say.
Gängan is a Yolngu settlement with around 90 permanent residents. It takes nearly four hours to get there by unpaved road from the former mission station of Yirrkala. The mission was established in 1935 and by the late 1960s had become the permanent place of residence for the majority of the immediate region's Yolngu population. However, in the 1970s many people began to move back to their own clan countries to live in small settlements that are referred to today as "the homelands."

Yinimala and Gunybi grew up on the homelands, and like many other Yolngu they wish to continue to build their lives there. Yinimala refers to the deep foundational (djalkiri) connection to place- - "where the songlines start." He connects the present determination to stay on "the land" with the struggles of his grandparents' generation to establish their land rights. The Yirrkala Church Panels are an important reference point. In 1962, as the result of an innovative collaboration between the clan leaders of the region, two panels of sacred clan paintings were set on either side of the altar of the Yirrkala church in a statement of the equivalence between Christianity and Yolngu religious practice (H. Morphy 2011). Gunybi's winning works are in direct continuity with these panels, both in terms of themes that reference ancestral connections to land and in their political import. Yinimala develops the theme of the equivalence and compatibility of Yolngu and Western knowledge in the future trajectory he envisages. He emphasizes the Yolngu desire to share, and at the same time he references a global outlook: "We are still sharing that culture to other parts of the world, and we are still converting each other." The winning of an arts award is itself a sign of successful engagement with the wider Australian society, but Yinimala places particular emphasis on the Indigenous Protected Area and its associated ranger program, which he sees as offering significant employment opportunities for Yolngu living on their country.

Yolngu often use public occasions such as exhibitions, book launches, and welcoming ceremonies to convey their concerns about government policy. Yinimala's speech was partly an implicit criticism of the recent trajectory of Northern Territory and Commonwealth Government policy, which is making life more difficult for Yolngu living on their homelands. At the core of current policies directed to the Aboriginal population of the Northern Territory lies the Northern Territory Emergency Response (NTER) of 2007, 
which is now set to continue for another decade under the rubric "Stronger Futures."

We will return to a more detailed consideration of this complex of related policy initiatives, which have become known colloquially as "the Intervention," and to their present and likely future effects on the trajectory of Yolngu life on the homelands. But first we consider how the currently dominant paradigm of Australian Aboriginalist anthropologythe intercultural (see, e.g., Hinkson and Smith 2005) models the postcolonial trajectories of Aboriginal sociocultural forms and how this paradigm interacts with the view from government.

Anthropologists with utterly opposed views on the Intervention have found the concept of "the intercultural" compatible with their analyses (e.g., Altman 2009; Sutton 2009). This reflects a problem that they share with government policymakers: the difficulty of imagining a future in which Aboriginal Australians are integrated into Australian society yet simultaneously continue to be selfdetermining.

We certainly concur with the view that the trajectories of Aboriginal forms of sociality have been and will continue to be significantly influenced by their articulation with the wider society. It is clear from Yinimala's statement that he perceives himself as living and acting in a world that contains "technology" and in which Yolngu are embarking on a "new journey." But we argue that the preeminent context for forming and reforming, and enacting and reenacting, the Yolngu way of being in the world is not the intercultural spaces where Yolngu interact with settler Australians. Instead, we suggest that in conceptualizing the problem of anthropological interpretation and in providing a framework for critiquing policy, the concept of "relative autonomy" is of much greater utility than the intercultural.

Our use of the term relative autonomy will be developed in apposition to the idea of the intercultural. The problem with concepts such as "the intercultural" and "hybridity" is that they are predicated on the interaction of two or more different entities, yet what those "entities" are either is difficult to specify or is left largely unspecified. We begin from a Yolngu perspective; their rhetoric acknowledges their encapsulation within the state but nevertheless argues for developing relationships with non-Yolngu Australians in the context of the mutual recognition of and respect for difference. This implies the possibility of participating in economic or cultural activities that enable them to engage with aspects of the wider Australian society without changing or compromising other aspects of their way of life or their beliefs.

We see the principle of relative autonomy as operating both within Yolngu society and in the articulation of Yolngu society with the wider world. Both frames are necessary. They allow for the analysis of the dynamics of interaction and change in the context of the articulation between Yolngu society and the encroaching settler society without resort to the reification of cultures as bounded systems. Relative autonomy not only connects with Aboriginal discourses at local and national levels but also provides a framework for conceptualizing an "economy in place."

The Intervention is an example of the failure to think through the implications of degrees of Aboriginal autonomy within the state as well as the failure to recognize that culture is not a veneer that can be selectively stripped away but, rather, is integral to people's engagement with the world, including their engagement with the wider settler economy. In the second part of this article, we review the trajectory of the Yolngu homelands movement, viewed as a project motivated by the desire to protect the relative autonomy of the Yolngu sociocultural system. We then consider in some detail the measures of the Intervention, its impact, and the Yolngu response.

\section{UNPACKING "THE INTERCULTURAL"}

Francesca Merlan originally introduced the concept of "the intercultural" to Australian anthropology in her influential book Caging the Rainbow (1998). The concept as she defines it is multiaspectual. The inter in intercultural is aimed to keep "engagement between" Aboriginal and non-Aboriginal people in view at all times (Merlan 2005:167). It alludes to the intersubjective in phenomenological theory, with particular reference to subjectivity arising out of interaction (Merlan 2005). Merlan refers to two other senses in which the inter can be conceptualized. One is that there is "a significant, sharp socio-cultural difference between two (at least) kinds of people in town, Aborigines and others" (Merlan 2005:169-170). The other is the inter of categories, which are reproduced and reshaped through interaction rather than pregiven (Merlan 2005). There are also spatial and event-focused dimensions to the inter, which on occasions can be read to imply that some locations are more intercultural than others - for example, the township of Katherine as opposed to the more remote communities of the region. The different senses in which intercultural is used signals the complexity of the theoretical problem with which Merlan grapples, in which different Aboriginal people are both part of and separable from the wider Australian society according to multiple factors and circumstances.

Merlan's key case study $(1998,2005)$ concerns the interpretation of an event that Julie, one of the Aboriginal people with whom she worked, observed in her youth and reported to her mother. Julie saw workers digging up the road in the center of the town of Katherine (Merlan 1998). She watched them extract a red object that they later buried in the garbage dump out of town. Her mother interpreted this object as a rainbow serpent, a spiritual being that, if disturbed, can bring about catastrophic events.

Interestingly, the "interaction" in this case does not involve the road builders beyond the fact that their actions and presence are the subject of Julie's observations. It is arguable that in this particular context the space itself is not intercultural because the road builders take no cognizance of the Aboriginal person's perspectives nor need representatives 
of the settler society do so in many circumstances because, as Merlan notes, the power differential is weighted in their favor (Merlan 2005).

Although the term intercultural carries connotations of sitting in between Aboriginal and non-Aboriginal society, Merlan does not argue for any simplistic dualism. However, in her analysis of the intercultural, Aboriginal actors seem to be affected by such encounters to a greater extent than their interlocutors from the other side. In this context, the intercultural can easily be transmuted into the place of the future or the place where the future is being made. This direction of movement is explicit in Merlan's conclusion, at least as far as the Aboriginal population of Katherine is concerned. Although Julie is unlikely to change her perspective on the existence of rainbow serpents, "notions of this kind have lesser experiential basis, distribution and currency among Aborigines than they did before" (Merlan 2005:180). Julie is thus positioned as someone in between. There was a time when Aboriginal people were separated from the urban world, and there is an inevitable future when Aboriginal people's interpretations of events will correspond more closely to those entertained by the settler Australian majority.

The intercultural, although acknowledging the importance of interaction between indigenous and nonindigenous sectors and individuals, tends to position Aboriginal people in a liminal, nonagentive space. Anthropologists who embrace the intercultural have found it difficult to respond to the policy trajectory that is typified by the Intervention because the intercultural, as does policy, focuses on the spaces where two cultures meet. The intercultural, once articulated as a conceptual space, has the potential to become the space where Aboriginal people gradually merge with the mainstream. This articulates neatly with the Interventionist view, where the non-Aboriginal side of the intercultural becomes in effect the default: it is where jobs are to be found; it speaks the language that will be spoken. The Aboriginal side quickly slips into the deficit category. There is interaction, but the direction of movement for Aboriginal people must be from deficit to participation in the mainstream. The non-Aboriginal side becomes less concerned with understanding Aboriginal society and more concerned with effecting change, with making the culture of the Other fit the mainstream.

As a result, concepts that began life as invaluable insights that facilitate the interpretation of data that were developed by anthropologists to understand aspects of Aboriginal sociality and its value structures - concepts such as "demand sharing" (Peterson 1993) and "the domestic moral economy" (Peterson and Taylor 2003) — are co-opted by policymakers as characterizations of negative cultural traits (Altman 2011) that handicap people in their move toward an inevitable future. As Elizabeth Povinelli has written, "the West as a general idea would claim the future and claim the potentiality of individuals and assign the past and the constraint of individuals to others - or, it would recognize that these were the values of non-liberal cultures" (2010:25).
The Australian case resonates with similar cases that occur globally in the context of development, involving processes that can be viewed as integral to the continuing trajectory of colonial capitalism (Escobar 2008; GibsonGraham 1996). The characterization of Aboriginal lifeways in terms of cultural deficit and community dysfunction almost explicitly requires the Aboriginal population to adopt the culture of their colonizers if their children are to be part of the future (see Sutton 2009). Such characterizations encourage the view that the displacement of people and their relocation are an inevitable part of the solution to their problems (Escobar 2008).

\section{INTRODUCING RELATIVE AUTONOMY}

In essence, the problem that Merlan is addressing concerns the ways in which processes of group and individual identity formation based on cultural difference are integrated within the frameworks of action and the political, economic, and social institutions of complex modern states. The state, and the global nexus of which it is a part, clearly impact the future trajectories of encapsulated subgroups, and individuals are continually moving between different frames of action. However, this does not alter the fact that those different frames exist, in terms of both systems and regimes of value (Austin-Broos 2009) and in associated forms of social organization. Those frames within which people act, whether we specify them as cultures, societies, or sets of actors in particular social fields, inevitably encompass loosely bounded, emergent, transforming, and internally differentiated sets of people. When such entities are incorporated within the boundaries of a state, the nature of the state's political structure will influence and constrain how those entities will change over time. However, placing the prime theoretical focus on the locale of interaction, as the concept of the intercultural tends to do, risks relegating those relatively autonomous groups to the status of epiphenomena. In Merlan's words, "The scene is not one of autonomy, but of still unequal, intercultural production" (Merlan 1998:181). The advantage of the concept of relative autonomy is that it begins with an acknowledgment of difference as well as a recognition that particular kinds of difference influence processes of articulation and adjustment.

Working with the Yolngu people of northeast Arnhem Land over a period of nearly 40 years, we have been continuously aware of the strength and sophistication of their engagement with the outside world. We have shown ways in which Yolngu have entered into relationships with outsiders to maintain their autonomy - in particular in the areas of land rights (F. Morphy 2009) and religious practice and cultural production (H. Morphy 2008, 2009). We have argued that, both within Yolngu society and in its articulations with the encompassing world, this autonomy has always been relative rather than absolute (H. Morphy 2011; Morphy and Morphy 2011). Rather than becoming "intercultural," Yolngu systems and subsystems remain relatively autonomous. 
They change in response to external pressures while maintaining their own distinct trajectories.

Our use of the term relative autonomy references its use in the writings of Louis Althusser (1969) and Maurice Godelier (1977) in the sense that we recognize the relative autonomy of social phenomena that can be identified as analytically distinguishable components of a sociocultural system. However, our use of the phrase is more generalized than its containment within the framework of structural Marxism would allow. Althusser was concerned with avoiding any form of simplistic economic determinism by acknowledging that cultural and ideological factors could have relatively independent impacts on the trajectory of a particular society. Although Althusser still asserts that economic structures were determinant in the "last instance," he adds the qualification that "the economic dialectic is never active in the pure state; in history, these instances, the superstructures, etc.- are never seen to step respectfully aside when their work is done ... From the first moment to the last, the lonely hour of the 'last instance' never comes" (1969:113).

Godelier's concept of relative autonomy owes much to Althusser, and it is a central component of his critique of anthropological approaches to the economy (Godelier 1977). Godelier (1977) did indeed reference Murngin (Yolngu) when he noted W. Lloyd Warner's (1958) failure to identify or discover any economic structure existing separately from kinship relations. Central to Godelier's theoretical framework is the idea that economics, inasmuch as it involves relations of production, cannot be separated from other social relationships. The same institution can operate in different domains; that is, kinship or political structures can function to organize relations of production and can also be integral to religious practice and ideologies. Nonetheless, Godelier goes on to argue that it is insufficient to assume that kinship or politicoreligious factors play a dominant role simply because they integrate all other social relations: as he puts it, "a social factor can only 'integrate' others if it assumes several distinct functions, linked with each other by some kind of hierarchy" (1977:35). In the end, he too implies that there is a hierarchy of causal factors and that the aim is to discover laws that "express the unintentional structural properties of social relations, their proper hierarchy and their articulation on the basis of determined modes of production" (1977:62).

Godelier's (1977) theoretical perspective was motivated partly by a desire to get away from the stasis of functionalist systems models, which, he argued, positioned social systems in a state of equilibrium and saw all change as being generated by external factors. His model is dynamic in that it allows both for the connectedness of systems and, at the same time, for the fact that coherence is always emergent. Jonathan Friedman summarizes Godelier's thinking when he writes that "the social order is a system ... [that] consists of a set of tendencies that are relatively autonomous with respect to their internal properties but [which are] never- theless joined together in the process of social reproduction" (2012:213).

Our use of the concept of relative autonomy does not require the hierarchy of determination inherent in structural Marxism nor do we adopt an explicitly systems model of society, but we do argue that in the context of the processes of articulation between Yolngu society and the encompassing colonial and postcolonial state we need to take into account the particular ways in which society is constituted as a relative whole, albeit one that is encapsulated within the wider state system.

We apply the term relative autonomy at two levels. The first concerns the relationships between different domains within the same regional sociocultural system - for example, between the kinship system, the system of technology and production, and the ideational system. In the Yolngu case, patterns of residence and of kinship relations have shown remarkable continuity over the postcolonial period, whereas the hunter-gather subsistence economy has been transformed into a mixed economy in which hunting and gathering supplements the whole. The second level of application is in the context of the interaction of sociocultural systems that were previously on very different historical trajectories. We argue that the sociocultural trajectory of the Yolngu people of eastern Arnhem Land was and remains very different from that of the encapsulating "dominant" settler society. "Relative" here refers to the fact that adjacent societies that interact over periods of time inevitably influence each other and create mechanisms and modes of adjustment that then ramify internally.

The two uses of relative autonomy are related. The structures and processes of articulation within regional sociocultural systems, which ensure that the autonomy of any one domain is only relative, give the overall society characteristics that differentiate it from others that have fundamentally different histories. On the one hand, these internal structural relations are extremely durable because individuals are socialized into them (F. Morphy 2007). On the other hand, communication and articulation between relatively autonomous worlds have always been integral to the history of human societies, and some individuals move easily between different worlds; anthropologists, for example, are trained to do so. In postcolonial contexts, such processes have become significant components in trajectories of change.

\section{RELATIVE AUTONOMY IN THE POSTCOLONIAL TRAJECTORY OF YOLNGU SOCIETY}

Until the 1920s, Yolngu society was largely unaffected by European colonization. The first mission was established in that decade at Milingimbi, in the northwestern part of the Yolngu region. Following the killing of the crew of a Japanese pearling vessel at Caledon Bay in the eastern part of the region in 1933, the Yolngu region was brought under settler control through the establishment of further Methodist mission stations at Yirrkala and Galiwin'ku (Egan 1996). These 
missions developed as local service communities and were the focal point of initial postcolonial economic development. The Yolngu, although semisedentarized on the mission stations, continued to exploit the resources of the surrounding region and to maintain close contact with their traditional clan estates.

During the mission era, a process of adjustment occurred. Yolngu collaborated with the missionaries to develop an economy in place based on developing self-sufficiency in food production and housing, generation of cash income through craft production, employment in health and education, and the development of small local enterprises. This collaborative relationship enabled the mutual recognition of relative autonomy and a process of adjustment that facilitated articulation at the local level with the encapsulating society. On the Yolngu side, changes at Yirrkala ranged from the adjustment of ceremonial performance to fit in with the working week and the acceptance of mixed-gender classrooms to decisions by clan leaders to work collaboratively in the mission context and override traditional hostilities (Clarke 2010). The missionaries in turn accepted the need for flexible work practices that took into account ceremonial obligations and long absences living on the country and acknowledged Yolngu religious practices by including Yolngu sacred paintings within the body of the church.

In the early 1970s, many Yolngu began the move back out from the missions to establish settlements known as "homeland centers" or "outstations" on their own clan countries. This was part of a general movement that occurred across many parts of Aboriginal Australia, motivated in part by the struggle for land rights. In the case of the Yolngu living in Yirrkala, there was an additional incentive. In 1971 the mining town of Nhulunbuy was built close to Yirrkala, and the strip mining of bauxite began. The coming of the mine disrupted people's lives and made alcohol readily available to the community.

Since the 1970s, settlement patterns in northeast Arnhem Land have developed as a complex regional system with a rapidly increasing Yolngu population. The regional population of some 2,700 people is divided among the three hub communities of Yirrkala, Gapuwiyak, and Gunyangara, and 30 homeland communities. The distribution and composition of Yolngu communities is a spatial reflection of land ownership and of interconnections based on extended kin relationships (gurrutu). Patterns of movement between communities are highly predictable on the basis of both clan organization and individual kin relationships (F. Morphy 2007, 2008a, 2010).

Whereas Yolngu have strongly maintained their regional system of social organization, in other ways they have actively engaged with the structures, institutions, and economy of the settler Australian world that has encompassed them. Shortly after the beginnings of the homelands movement, the Methodist Overseas Mission ceded control of its missions, including Yirrkala, to incorporated village councils, and in 1985 the Laynhapuy Homelands Association was separately incorporated as a resource agency to service the growing homelands population. In the 40 years since the beginning of the outstation movement, the role of government funding in underpinning the homelands economy has gradually increased. Housing came to be provided through a grant-funded community-housing model administered by Laynhapuy, which was also charged with maintaining power, water, and other infrastructure in the homelands communities. Although Laynhapuy had some sources of independent funds, by the mid-2000s the majority of its income was in the form of tied grant funding from a number of Commonwealth and Northern Territory government departments (see F. Morphy 2008b).

Hunting and gathering, art and craft production, and welfare transfers continued to be significant components of the economy; however, government-funded positions in education and health and jobs funded through the Community Development Employment Program (CDEP), which was administered by Laynhapuy, also became important. Initially designed to replace unemployment benefits for Aboriginal people living in regions where conventional job opportunities are limited (see, e.g., Austin-Broos 2009; Morphy and Sanders 2001), CDEP became the mainstay of the homelands economy as both a source of income and a means of funding municipal jobs, such as garbage disposal, that in "mainstream" communities are funded through rates and taxes.

By the mid-2000s, the homeland communities in northeast Arnhem Land had become well established as part of a regional system, and they remain, voluntarily, largely drug and alcohol free. People's well-being compared favorably with that of the Yirrkala and Gunyangara township populations. For example, in the townships, high levels of alcohol and substance abuse are correlated with high levels of suicide among youth and young adults. Between January 2003 and January 2005, according to an unpublished report by the officer in charge of Nhulunbuy Police Station, there were over 40 reported suicides or attempted suicides among Yolngu in the region, and "alcohol is significant in the majority of cases" (Fuller 2005:11). Not one of these reported cases occurred at a Laynhapuy homeland community.

The homeland population and its community leaders remain determined to live on the homelands for a number of reasons. Yinimala, the speaker mentioned at the beginning of this article, emphasizes these when he talks of culture, country, and the "djalkiri, where the songlines start, where the stories are, where the ancestors [are].” Attachment to their ancestral lands, the ability to maintain the kin-based nature of their society and their ceremonial system, and continued access to their preferred foods and other local resources drive this determination. Yirrkala, with its proximity to the mining township of Nhulunbuy, is viewed negatively.

It is clear that the economic base of the homelands is underpinned by the non-Yolngu settler economy, yet this does not transform the homelands into "intercultural" spaces. Jon Altman's (2006) analysis of the economy of the Kunwinjku 
of western Arnhem Land shows a situation that has much in common with the Yolngu case to the east, although there are fundamental differences in social organization and regional context and history. Altman's model of a "hybrid" economy in which he represents the homelands economy as comprising three sectors - the customary, the state, and the market - has the effect of separating the economic from the sociocultural context or of isolating the customary as a sector that is different in kind. Altman sees the hybrid economy as being nested within the overall framework of the intercultural, yet Merlan is able to criticize his analysis on the basis that it fails to take account of the fact that all sectors involve connections between cultures. She argues against Altman's placing of hunting and art production in the customary sector because such activities involve connections beyond that sector: hunters employ guns and artworks are sold to art galleries (Merlan 2009). Artists "come to be associated with persons beyond the local scene, and thus become involved in relationships which have new social elements and values" (Merlan 2009:278). Yet it is equally unilluminating to label these developing engagements with the broader economy as "intercultural" simply because they cross-cut cultural boundaries. The way out of this dilemma is to invoke the concept of relative autonomy. The trajectory of Aboriginal society articulates with that of the wider society in such engagements, but the processes of value creation, on the Aboriginal side, are motivated by the desire and determination to maintain an autonomous sociocultural space.

We would argue that Altman's "sectors" represent options for Aboriginal people in remote areas in their engagement with the encompassing state, enabling them to create an economy in place that articulates with the overall sociocultural trajectory of their society. Yolngu engagement with all three sectors comes from a relatively autonomous position, which operates in dialogue with the wider contemporary context of their lives.

\section{RELATIVE AUTONOMY AND YOLNGU AGENCY}

In analyzing Yolngu mortuary rituals over time, we have shown them to be a body of practice with a trajectory that is relatively autonomous and that can be understood only partly in terms of adaptive responses to new circumstances (Morphy and Morphy 2011). The thematic structure of contemporary burial ceremonies, the song cycles, the forms of paintings, and the roles played by different categories of kin are remarkably similar to those described and recorded by Warner (1958) and Donald Thomson (Peterson 1976), who worked with Yolngu in the 1920s and 1930s, respectively. Since colonization, major changes have undoubtedly occurred. The spirit journey of the deceased used to be guided in part by a painting on the body's chest. This has been substituted successively by a painting on the coffin lid, by painted cloth and screen-printed cloth, and by paintings on bark or cloth placed beside the body (Morphy and Morphy 2011). Primary burial has, over time, become the major focus of ceremonial activity, incorporating phases of initiation rituals that used to be separate events. These changes have been facilitated by technological change (the body can be kept in a portable morgue, allowing time to organize a major event) and also reflect a growing emphasis on ritual performances that are inclusive of the whole community, leading to an increased frequency of open as opposed to restricted ceremonies. The changing trajectory of Yolngu mortuary rituals has been multiply determined by the operations of factors that are relatively autonomous from one another. The changes have been influenced by articulation with the wider Australian society and involve the incorporation of new technologies, but mortuary rituals are far from occupying an intercultural space; they remain categorically Yolngu and integral to the reproduction of Yolngu society (Morphy and Morphy 2011).

Our adoption of the concept of relative autonomy is partly motivated by its synergistic relationship with Yolngu understandings of the relationship between their society and the encompassing non-Aboriginal world. Yolngu strongly emphasize parallels between their own institutional structures and cultural practices and those of outsiders as a means of asserting the value of their own way of life - in religion (H. Morphy 2005), law (F. Morphy 2009; Williams 1986, 1987), and cultural production (H. Morphy 2011).

Yolngu explicitly frame their orientation to the present and future in terms of the often-employed trope "living in two worlds," as when a Yolngu witness stated during his evidence in the Blue Mud Bay native title case: "We're living in two worlds today, for example. Your world is change every day or every month or every year. My law and my story, it can't change" (Gawirrin Gumana \& Ors v. Northern Territory of Australia \& Ors, Federal Court Transcript 2004:284.02-04). This orientation is also implicit in the grammatical constructions that people employ when they discuss the relationships between Yolngu and European bodies of law. The following example comes from a videotaped interview in which Djambawa Marawili talks to Howard Morphy about ranger programs as a context for exchange of knowledge between ngäpaki (white people) and Yolngu:

\footnotetext{
Djäka muka rom-gu bitjan nhakuna, ngilimurru nguli djäka-ya nho-kala-nguwu ngäpaki' -wu rom-gu [Indeed, we and you (white people) will protect (Yolngu) law just as we and you protect your white people's law]. [Interview, September 21, 2006; transcription and translation by Raymattja Marika-Mununggiritj and Frances Morphy]
}

In the context of the wider discourse, the first mention of rom (law) can be taken as referring to Yolngu rom. Djambawa uses the inclusive form of the first person plural, ngilimurru, to include ngäpaki (with Howard as the included representative of ngäpaki) as joint guardians of Yolngu rom in the context of the ranger program. But he does not think of them as the holders of this law, just as he does not think of Yolngu as holders of ngäpaki law, as is evident from the second part of the utterance. He speaks of "your" (nhokalanguwu) ngäpaki law as something that Yolngu, together with ngäpaki, protect. 
Yolngu often speak also of the process of "two-way learning." Two-way learning was formalized as a practical Yolngu initiative to include their system of knowledge within the school curriculum as a parallel mode of education to the Western curriculum (Marika-Mununggiritj 1999). The inclusion of Yolngu knowledge within the constraints of the school system involved changes to the ways in which such knowledge is passed on by codifying and reproducing it in the form of books and packaged teaching materials. It also introduced a new context of transmission. Whereas outside of school, clan membership and gender are factors that structure the transmission of knowledge, the school classroom is a mixed-gender, multiclan environment. In including Yolngu knowledge in the school curriculum, Yolngu were required to make choices that they might not otherwise have made, but they did so as conscious agents, weighing up the advantages against the disadvantages. Their argument for two-way education is that if Yolngu knowledge is left outside the school system, then Western knowledge systems will be privileged. The inclusion of Yolngu knowledge as a separate component within the school curriculum presupposes its difference yet simultaneously asserts its equivalence.

Yolngu certainly do not subscribe to the view of human societies as static systems, although they insist that the "law and story" that underpin the Yolngu way of being in the world “can't change." Later in the same recorded interview, talking about the means to control access to restricted places, Djambawa says:

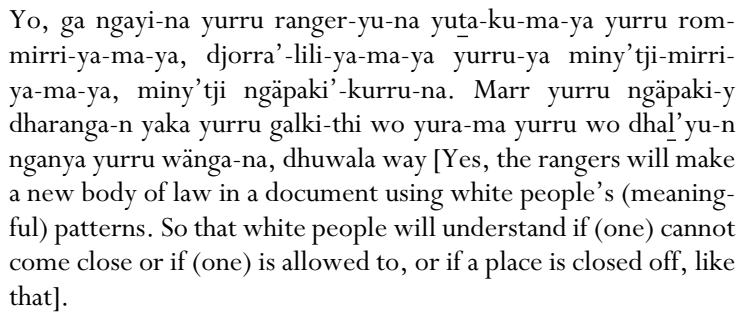

The Yolngu view, articulated here by Djambawa and in the introductory excerpt from Yinimala's speech, is that they are selectively embracing new technologies to protect the autonomy of their system of law and their relationships to country. In his choice of the word miny'tji, Djambawa is drawing a parallel between writing as a system of meaningful signs (to ngäpaki) and the ancestrally derived patterns in the land and in the Yolngu painting tradition that signify the connection of Yolngu to their land. In their interactions with ngäpaki, Yolngu are open to new ways of doing things that may have some effect on the trajectory of their socioreligious system but that do not, in their estimation, challenge its core values.

In the case of settler colonial societies and encapsulated indigenous societies, the adjustments required by the former of the latter are often unequal. The sociocultural trajectory of the Yolngu people of eastern Arnhem Land has been very different from that of the encapsulating "dominant" society. Yolngu have been engaged in a constant process of adjustment through interaction that ramifies internally. But we would argue that models that move the focus to the space in between - for example, hybridity theories and theories of the intercultural - deflect attention from the agency of people such as Yolngu and from the frames in which core variables and value-creating processes are located.

\section{CONTRADICTORY POLICIES AND DIFFICULT ARTICULATIONS}

Seen over time and in contrast to the consistency of the Yolngu position, the position of the state has been characterized by ambiguity and inconsistency. In the early years of effective colonization, government control over the Yolngu region was exerted indirectly through the instrument of missionization. The dominant ideology was protectionist and assimilationist; governments, reflecting the prevailing settler view, envisaged that Aboriginal people, having first been "civilized," would eventually be absorbed within the mainstream. However, by the late 1960s, following years of political action by Aboriginal people and in a political climate that brought human rights to the fore, the opportunity was created for the recognition of Aboriginal land ownership in areas where they had not already been dispossessed (Attwood 2003). The Commonwealth's Land Rights (Northern Territory) Act of 1976 (ALRA) acknowledged the distinctive nature of Aboriginal forms of land ownership based on communal title and an enduring spiritual relationship to the land. Mechanisms that facilitated the process of articulation between local Aboriginal land-owning polities and the state were created in the form of mediating institutions such as land councils and land trusts. This allowed Yolngu institutional processes a space to function within the new framework established by the state.

This recognition in law of the durability of distinctive Aboriginal systems of socioreligious organization carried an implicit recognition by the state of the relative autonomy of those systems. But recognition was never fully and explicitly articulated, despite the prevailing rhetoric of "selfdetermination" for Aboriginal people. Had it been, it might have signaled to later governments that the rapid social transformation required to "reform" Aboriginal forms of sociality so that they conformed to an idealized version of mainstream Australian individualism was a misguided policy objective (see also Martin 2011).

The policy of self-determination that developed after the granting of land rights saw the demise of the mission as a mediating institution. The new modes of articulation introduced by government failed to include such structural and supporting elements as long-term staff who were dialogically engaged at the local level in the adjustment process. The consequence of the withdrawal of this supporting environment was the attrition of local economic enterprises. Government funding to Aboriginal communities and individuals became increasingly focused on tied grants and welfare payments rather than on the support of local enterprises. Although Yolngu had been granted freehold title to their land on the 
basis of their difference, there was little attempt to implement policies that would support them to develop this asset according to their own aspirations.

The crucial missing link was the failure to give broader recognition to the relative autonomy of Yolngu society in the process of its articulation with the wider Australian society. There was another factor that conspired to keep the concept of relative autonomy from surfacing explicitly into the domain of policy. In 1967, in sympathy with the rightsbased atmosphere of the times, the Australian population voted overwhelmingly in a national referendum on the Australian constitution for the indigenous peoples of Australia to be counted as part of the population in the five-yearly national census. As a consequence, with the introduction of an "indigenous identifier" in the census, a new statistical entity now came into existence - the self-identified national "indigenous population" - and its demographic and socioeconomic characteristics began to be compared, on a national level, with those of the population at large. A "demography of disadvantage" began to emerge (Taylor 2009). At this scale, with reference to such a heterogeneous and geographically dispersed population, the concept of relative autonomy has little traction, and its potential emergence into policy thinking was effectively blocked at the same time as it was being implicitly recognized in the arena of land rights in the Northern Territory.

In recent years, government policy in "remote" Australia has been increasingly oriented toward building an economy based on the exploitation of mineral resources. The "solution" for regional economies has been to link them to the mining industry. Half of the Northern Territory of Australia comprises Aboriginal-owned land, and Aboriginal agreement is required to facilitate mining development. In this context, it is hardly surprising that many of the solutions proposed to mitigate Aboriginal disadvantage have involved employment in the mining industry or the use of mining royalties. Government policy has focused on the development of the mining industry and on imagining ways in which the resulting resources can be used to advance its agenda for "closing the gap" between indigenous and nonindigenous Australians. Encouraging Aboriginal people to become residents of designated "growth towns" and become job ready for employment in the mining industry and its associated regional economy has come to have a greater priority than facilitating Aboriginal people's development of their regional economies according to their own priorities.

\section{THE CRAFTING OF THE INTERVENTION}

We are now in a position to review the Intervention in more detail and show how its measures cut across the relatively autonomous regional trajectory that had developed in northeast Arnhem Land in the postcolonial era. Over time, both in the Northern Territory and in Australia as a whole, the Aboriginal population continued to show statistical disadvantage and low levels of participation in the mainstream economy. In the 2000s, the Australian government began to argue that the rights-based policy direction set in the 1970s was responsible for this situation of disadvantage and disengagement and for the problem of entrenched welfare dependency. In the pithy words of one federal minister for Aboriginal Affairs, Aborigines in the Northern Territory were "land rich but dirt poor" (Vanstone 2005:4).

The Intervention comprises a series of initiatives from the Territory and Commonwealth governments, beginning in 2007 with the Northern Territory Emergency Response in the final months of the Howard government and continuing under subsequent Labor governments. These policies are designed to intervene in Aboriginal lives, with the overt justification of ameliorating Aboriginal disadvantage. In hindsight, the NTER can be seen as a dramatic stage in a policy trajectory that had begun to emerge earlier in the decade (see Austin-Broos 2011). Government policy is perhaps inevitably clothed in rhetoric, and during the first decade of the 21st century, the rhetoric in Aboriginal Affairs had developed around a set of terms including practical reconciliation, normalisation [sic], welfare dependency, the real economy, and closing the gap. The terms stem from a particular diagnosis of the causes of disadvantage and the consequent "remedies" that are proposed. There is no doubt that welfare dependency among Aboriginal people had increased during the period of "self-determination," but by a process of elision, the rights-based nature of that policy era came to be seen as a direct cause of welfare dependency. Despite their gains in terms of land rights, Aboriginal Australians were seen to have failed to become "job ready." They had not acquired the numeracy and literacy skills of other Australians; further, they had failed to develop a "normal" work ethic. The solution was to enable and encourage them to join the mainstream and participate in the "real" economy by acquiring the necessary skills and work habits.

Few would argue against the development of policies to address socioeconomic disadvantage, and most would agree that a period of laissez-faire policy had contributed to some of the problems that existed. However, the diagnosis failed to take account of the diversity of Aboriginal societies and the capacities of Aboriginal people; the quantitative measures of disadvantage failed to acknowledge lifestyle factors that ameliorated statistics of disadvantage (Rowse 2010); and the employment solutions that were proposed failed to take account of the nature of the "real" economy in the regions where many Aboriginal people live.

The NTER began as the Howard government's response to the Little Children Are Sacred report on the sexual abuse of Aboriginal children in the Northern Territory (Wild and Anderson 2007). The report was careful and detailed, and the investigators did uncover evidence of sexual abuse of children in some communities. The extensive list of recommendations emphasized the need for community engagement in addressing the problem and the facilitation of communityled solutions. The NTER legislation ignored the spirit of the report and the majority of its recommendations (see Altman and Hinkson 2007). 
The provisions of the NTER were built on an initial designation of all Aboriginal lands held under the ALRA as "prescribed areas" and all the major communities on those lands (over 50 communities) as "prescribed communities," in addition to nearly 50 "town camps" (discrete Aboriginal communities in urban areas). A task force coordinated by Major General Chalmers was set up, and sections of the armed forces were co-opted to provide logistical backup for the efforts of NTER personnel. Each prescribed community was placed under the oversight of a Commonwealth-appointed government business manager to coordinate NTER activities, and each became subject to measures such as blanket bans on alcohol and pornography, compulsory health checks for all Aboriginal children including investigation for signs of sexual abuse, and compulsory income management of 50 percent of all welfare payments to Aboriginal people.

The category of "prescribed community" only included major hub communities such as Yirrkala, but many of the provisions of the NTER - income management, compulsory health checks, and the ban on alcohol and pornographyapplied also to the inhabitants of homelands by virtue of their Aboriginality and their inclusion in a prescribed area. The introduction of many of these changes required the suspension of the Racial Discrimination Act because the NTER applied to all and only Aboriginal people in the prescribed communities and their hinterlands.

Some of the NTER measures were subsequently modified. The compulsory screening of children for signs of sexual abuse was replaced by voluntary general health checks. In Yirrkala, the blanket ban on alcohol was removed and replaced by a previously negotiated local solution based on a permit system for take-away sales that applied to the regional population as a whole, including the non-Yolngu inhabitants of the mining town of Nhulunbuy.

Shortly after the declaration of the NTER, the Howard government announced that it was going to abolish CDEP, which it had long characterized as "sit-down money." However, the immediate reason for ending the scheme quickly was that CDEP payments could not be defined as welfare and hence could not be income managed. The Howard government lost power before it could implement this measure; succeeding Labor governments have continued to work toward phasing out the program.

The Labor government has continued the development of policies designed to encourage the recentralization of Aboriginal people into a few major population centers, now designated as "growth towns." The government has ceased to fund housing in the homeland communities. In the "growth towns," the government is attempting to introduce a new public housing model, first recommended in a report commissioned by the Howard government (PriceWaterhouse Cooper 2007), in which the government controls the housing stock and the terms and conditions of rental agreements. In settlements on Aboriginal land, the traditional owners are required to lease land to the government for this new housing. The government business managers have worked with representatives of the "growth-town" communities to devise Local Implementation Plans (LIPs) for each community, framed by a series of policy measures designed to "close the gaps" in housing, health, infrastructure, and employment opportunities. Yirrkala's LIP (Commonwealth of Australia 2011) is completely silent on the future of the surrounding homelands.

The emphasis on making people "job ready" was also reflected in recent changes in education policy that ended bilingual and bicultural education in schools where such programs had been established for many decades (Simpson et al. 2009). In 2008, bilingual education in the Northern Territory was abolished in favor of a policy that decreed that the first four hours of teaching in schools would be exclusively in English.

As the Intervention was being implemented, the Northern Territory was simultaneously transforming local government arrangements with the introduction of a system of regional shires. Most Aboriginal settlements and all discrete Aboriginal communities on ALRA lands had hitherto been administered through local Aboriginal community organizations whose major source of revenue was a variety of tied grants from the Commonwealth and Northern Territory governments. The shires replaced these previously existing forms of local government. Local community associations, with their Aboriginal boards, were disbanded, and their assets were transferred to the new shire system. Service provision to outstation settlements was explicitly excluded from the remit of the shires. Homelands resource organizations such as Laynhapuy have survived with a diminished role; they are no longer able to source funding for new housing for the growing homelands populations, and they preside over an ever-shrinking CDEP program.

\section{YOLNGU RESPONSES TO THE INTERVENTION}

Yolngu see in government policy a disregard for their aspirations in favor of a model that fits with the state's desired transformation of Yolngu society. Yolngu have resisted many of the recent policy changes; the land-owning clans in some of the Yolngu "growth towns" have not yielded to the pressure to sign leasing agreements that are the condition of building new housing, and the population of the homelands has not moved en masse into the growth towns despite the attrition of support for their communities. So far Yolngu are able to survive on welfare payments supplemented by hunting and gathering and art production. It is also the case that the limited government investment in the regional economy and the minimal provision of services over many years has meant that they have little to lose.

Overt opposition is becoming increasingly evident. In 2009 we were present at a celebration at Yilpara on the shore of Blue Mud Bay, 60 kilometers by road from Yinimala and Gunybi's home at Gängan. After a ten-year struggle, Yolngu had recently won the Blue Mud Bay case, a major case in the Federal High Court that confirmed their title under the ALRA to the intertidal zone. We had worked on the claim as expert witnesses. At the time of this celebration, 
the Northern Territory government had just released its "Working Future" policy, which confirmed, among other things, that there would be no funding for new housing in communities such as Yilpara and Gängan. The event at Yilpara had brought politicians and media representatives from across the nation to share in the celebration of the High Court victory. Yolngu organized a ritual burning of copies of the Working Futures report to draw attention to their concern about its contents.

More recently, a group of Yolngu leaders has issued a statement on the Internet calling for the abandonment of the proposed "Stronger Futures" legislation. They ask government to "end their interventionist policies and agendas, and return to a mindset of partnership based on the principles of Self-Determination" (Yolnguw Makarr Dhuni [Yolngu Nations Assembly] 2012:2). This statement is receiving increasing and widespread support from individuals and organizations around the country (including former Prime Minister Malcolm Frazer, whose government passed the ALRA into law).

Like any government of a complex modern state, the Australian government is not entirely monolithic in its policy position. There are areas in which Yolngu have been able to exert their agency to develop initiatives that fit with their desired trajectory, and in these areas they have continued the process of positive engagement with the encapsulating state. These initiatives involve selective engagement with particular government agencies to take advantage of opportunities that enable them to maintain their relative autonomy in place.

There are a number of areas in which Yolngu have broadened the economic base of their region in recent decades. The Aboriginal art and craft industry is a generator of significant income, with a national and international market. Yolngu are major players in this industry; Buku Larrnggay Mulka at Yirrkala is one of the most successful community-owned art centers in Australia, and its artists, the majority of whom live on the homelands, have won many national and international accolades. Land-management programs and their associated ranger programs have developed rapidly in recent years with the establishment of the Dhimurru and Laynhapuy Indigenous Protected Areas as part of the National Reserve System. There is also an embryonic tourist industry based on fishing and eco- and cultural tourism. All of these sectors of the local economy are dependent on Yolngu participation and on their specialist knowledge of their region, and all involve the use of the resources of the region as a whole. If supported and encouraged, these developing industries could add value to each other and provide job opportunities to people living in the homeland regions. Although the present "real" economy of the region is based on mining, government employment, and service industries, the potential for regional economic development is considerable if the Aboriginal population and the environment they have lived in and managed for generations are taken seriously into account.
The continuing hunter-gatherer economy of Yolngu people living on homelands is also an important component of the regional economy. Hunting, fishing, and gathering still provide a valued part of people's diet (see Barber 2005). The hunter-gatherer economy sustains a body of knowledge that underpins the ranger and land-management programs and is essential to the success of cultural and environmental tourism. The fact that Yolngu have maintained their rich cultural traditions in place not only has ensured the success of the art and craft industry but also provides the basis for effective land and sea management and the development of cultural tourism. The Yolngu knowledge base is a considerable regional asset.

\section{CONCLUSION}

In the majority of areas of the Northern Territory where the Intervention has taken effect, the rights-based legislation of the 1970s had enabled Aboriginal Australians to maintain or regain their ownership of large areas of land and to establish a decentralized pattern of settlement in the context of a relatively autonomous relationship with the state. Recent government policies have drastically affected the autonomy of both communities and Aboriginal individuals and have focused on the development of centralized communities or "growth towns." These areas are seen as sites at which Aboriginal disadvantage will be addressed through integration into the economic mainstream. Such policy takes little account of the place-based values that underlie local aspirations.

The government's policy of mainstreaming imagines a future in which Yolngu live in nuclear family households in regional towns, enjoying the same "opportunities" as other Australians. The homelands communities have been placed in an increasingly liminal position. They are physically incorporated in the shires but are not of them when it comes to service provision. They are subject to the constraining measures of the NTER but receive none of the alleged benefits. They are denied new housing. The CDEP program that underpins their economy is being gradually dismantled.

The imagined economic future under the mainstreaming model runs counter to the aspirations of homelands Yolngu and the trajectory they have created (see F. Morphy 2008a; Morphy and Morphy 2008). Unless Yolngu can be persuaded to radically change their way of life and system of values, such a system has no hope of success. Yolngu do not have a closed idea of what their future will be and are willing to engage with others to develop it. But the vast majority of Yolngu who live on the homelands do not want to move into town. Yolngu, young and old alike, recognize the power of gurrututhe sets of relationships and obligations in which they are embedded and their attachment to their own country and ways of life. From their perspective, the essential need is to generate an economy in place.

The general direction of the most recent government initiatives, unless modified, will have the effect in the 
medium to long term of coercing Yolngu to leave the homelands by depriving them of resources. Rather than working in partnership with Yolngu and their support organizations, the government is deploying its resources in ways that may create precisely the problems that homelands-based Yolngu have been trying to avoid - living in overcrowded townships away from their own country, struggling to pass on to the younger generations a sense of their autonomous future as people with a distinctive culture and way of life.

As a population, Aboriginal Australians face a difficulty in developing forms of articulation with the state. One cause of this difficulty is their own diversity, which is a product of social, cultural, and demographic variation across the continent and of the colonial histories to which they have been subject. As a result, different modes of articulation have occurred in different parts of Australia. The present policy rhetoric of the state ignores all this diversity and is firmly fixed on two concepts: mainstreaming (or "normalization") and closing the gap - the quantitative measure for the extent to which mainstreaming has been achieved. Mainstreaming conveys the idea that, despite the internal diversity for which the state actually allows, there is a single and internally undifferentiated mainstream. The concept of the idealized mainstream means that Aboriginal Australians must be coerced (or encouraged to choose) to be "people like us" before they can choose to be different. This is clearly a logically flawed project. Aboriginal diversity and difference could instead be acknowledged as an aspect of a more conceptually complex mainstream in which multiple modes of modernity, instantiated in a multiplicity of relatively autonomous trajectories, are accommodated.

The concept of relative autonomy allows an escape from the double bind of opposed perspectives that either give false concreteness to Aboriginal societies as separate from the state or place too great an emphasis on the inevitability of a future built on individualized modernity within the state. To understand both the resistance of many Aboriginal communities to government policy and the failure of those policies to achieve their intended outcomes, it is helpful to understand Aboriginal forms of sociality and their associated value creation processes as relatively autonomous. Yet, we also need to build into our models the dynamic processes whereby, both as individuals and members of groups and communities, people articulate with the framework of the state in a globalized world. And here, in this "prescribed" space, the notion of the intercultural is undoubtedly of value.

Frances Morphy Centre for Aboriginal Economic Policy Research, Australian National University, Canberra, ACT 0200, Australia; frances.morphy@anu.edu.au

Howard Morphy Research School of Humanities and the Arts, Australian National University, Canberra, ACT 0200, Australia; howard.morphy@anu.edu.au

\section{NOTES}

Acknowledgments. This article has benefited greatly from the careful critical attention it received from six anonymous reviewers. Both its argument and its structure have been greatly improved as a result of their comments. We also thank in particular the former editor-in-chief of American Anthropologist, Tom Boellstorff, for his patient and painstaking shepherding of this article through the review process. Last, we thank Françoise Dussart for her critical support and for her translation of the abstract into French.

\section{REFERENCES CITED}

Althusser, Louis

1969 For Marx. London: Allen Lane.

Altman, Jon

2006 The Indigenous Hybrid Economy: A Realistic Sustainable Option for Remote Communities? CAEPR Topical Issue, 2. Canberra: Centre for Aboriginal Economic Policy Research, Australian National University.

2009 Contestations over Development. In Power, Culture, Economy: Indigenous Australians and Mining. CAEPR Research Monograph, 30. Jon Altman and David Martin, eds. Pp. 1-16. Canberra: ANU ePress.

2011 A Genealogy of "Demand Sharing": From Pure Anthropology to Public Policy. In Ethnography and the Production of Anthropological Knowledge: Essays in Honour of Nicolas Peterson. Yasmine Musharbash and Marcus Barber, eds. Pp. 185-200. Canberra: ANU ePress.

Altman, Jon, and Melinda Hinkson, eds.

2007 Coercive Reconciliation: Stabilise, Normalise, Exit Aboriginal Australia. Melbourne: Arena Publications.

Attwood, Bain

2003 Rights for Aborigines. Sydney: Allen and Unwin.

Austin-Broos, Diane

2009 Arrernte Present, Arrernte Past: Invasion, Violence, and Imagination in Indigenous Central Australia. Chicago: University of Chicago Press.

2011 A Different Inequality: The Politics of Debate about Remote Aboriginal Australia. Sydney: Allen and Unwin.

Barber, Marcus

2005 Where the Clouds Stand: Australian Aboriginal Relationships to Water, Land, Place and the Marine Environment in Blue Mud Bay, Northern Territory. Ph.D. thesis, Department of Archaeology and Anthropology, Australian National University.

Clarke, Bernard

2010 Larrpan ga Buduyurr: The Spear and the Cloud. Adelaide: MediaCom Education.

Commonwealth of Australia 2011 Local Implementation Plan: Yirrkala. http://www. workingfuture.nt.gov.au/Territory_Growth_Towns/ Yirrkala/docs/Yirrkala_LIP_signed.pdf, accessed June 15, 2012.

Egan, Ted

1996 Justice All Their Own: The Caledon Bay and Woodah Island Killings, 1932-1933. Melbourne: Melbourne University Press. 
Escobar, Arturo

2008 Territories of Difference: Place, Movements, Life, Redes.

Durham, NC: Duke University Press.

Friedman, Jonathan

2012 The Dialectic of Cosmopolitanization and Indigenization in the Contemporary World System: Contradictory Configurations of Class and Culture. In The Scope of Anthropology: Maurice Godelier's Work in Context. Laurent Dousset and Serge Tcherkézoff, eds. Pp. 212-245. Oxford: Berghahn.

Fuller, Tony

2005 Aboriginal Suicides in North East Arnhem Land, 2003-2004: An Overview of Current Suicide and Attempt [sic] Suicide Trends amongst the Indigenous Population in the Nhulunbuy Police District. Unpublished report prepared by the officer in charge, Nhulunbuy Police Station, Northern Territory Police.

Gibson-Graham, J. K.

1996 The End of Capitalism (As We Knew It): A Feminist Critique of Political Economy. Oxford: Blackwell.

Godelier, Maurice

1977 Perspectives in Marxist Anthropology. Cambridge, UK: Cambridge University Press.

Hinkson, Melinda, and Benjamin R. Smith, eds.

2005 Figuring the Intercultural in Aboriginal Australia. Special issue, Oceania 75(3).

Marika-Mununggiritj, Raymattja

1999 The 1998 Wentworth Lecture. Australian Aboriginal Studies (1):3-9.

Martin, David

2011 Policy Alchemy and the Magical Transformation of Aboriginal Society. In Ethnography and the Production of Anthropological Knowledge: Essays in Honour of Nicolas Peterson. Yasmine Musharbash and Marcus Barber, eds. Pp. 201-215. Canberra: ANU ePress.

Merlan, Francesca

1998 Caging the Rainbow: Places, Politics, and Aborigines in a North Australian Town. Honolulu: University of Hawai'i Press.

2005 Explorations towards Intercultural Accounts of SocioCultural Reproduction and Change. Special issue, "Figuring the Intercultural in Aboriginal Australia," Oceania 75(3):167182.

2009 Introduction: Recuperating Economic Anthropology. Australian Journal of Anthropology 20(3):269-284.

Morphy, Frances

2007 Uncontained Subjects: "Population" and "Household" in Remote Aboriginal Australia. Journal of Population Research 24(2):163-184.

2008a Redefining Viability: Aboriginal Homelands Communities in North-East Arnhem Land. Australian Journal of Social Issues 43(3):381-396.

2008b Whose Governance for Whose Good? The Laynhapuy Homelands Association and the Neo-Assimilationist Turn in Indigenous Policy. In Contested Governance: Culture, Power and Institutions in Indigenous Australia. CAEPR Research Monograph, 29. Janet Hunt, Diane Smith, Stephanie Garling, and Will Sanders, eds. Pp. 113-152. Canberra: ANU ePress.
2009 Enacting Sovereignty in a Colonized Space: The Yolngu of Blue Mud Bay Meet the Native Title Process. In The Rights and Wrongs of Land Restitution: "Restoring What Was Ours." Derek Fay and Deborah James, eds. Pp. 99-122. Abingdon, UK: Routledge-Cavendish.

2010 (Im)Mobility: Regional Population Structures in Aboriginal Australia. Australian Journal of Social Issues 45(3):363-382.

Morphy, Howard

2005 Mutual Conversion? The Methodist Church and the Yolngu, with Particular Reference to Yirrkala. Humanities Research 12(1):41-54.

2008 Becoming Art: Exploring Cross-Cultural Categories. Sydney: University of New South Wales Press.

2009 Acting in a Community: Art and Social Cohesion in Indigenous Australia. Humanities Research 15(2):115-131.

2011 "Not Just Pretty Pictures": Relative Autonomy and the Articulations of Yolngu Art in Its Context. In Ownership and Appropriation. ASA Monographs, 47. Veronica Strang and Mark Busse, eds. Pp. 261-286. Oxford: Berg.

Morphy, Frances, and Howard Morphy 2008 Not Seeing What Is There. Arena Magazine 94:40-43.

2011 "Soon We Will Be Spending All Our Time at Funerals": Yolngu Mortuary Rituals in an Epoch of Constant Change. In Returns to the Field. Signe Howe and Aud Talle, eds. Pp. 49-72. Bloomington: Indiana University Press.

Morphy, Frances, and Will Sanders, eds.

2001 The Indigenous Welfare Economy and the CDEP Scheme. CAEPR Research Monograph, 20. Canberra: Centre for Aboriginal Economic Policy Research, Australian National University.

Peterson, Nicolas

1976 Mortuary Customs of Northeast Arnhem Land: An Account Compiled from Donald Thomson's Fieldnotes. Memoirs of the National Museum of Victoria 37:97-108.

1993 Demand Sharing: Reciprocity and the Pressure for Generosity among Foragers. American Anthropologist 95(4): 860-874.

Peterson, Nicolas, and John Taylor

2003 The Modernising of the Domestic Moral Economy: Kinship, Accumulation and Household Composition. Asia Pacific Journal of Anthropology 4(1-2):105-122.

Povinelli, Elizabeth

2010 Indigenous Politics in Late Liberalism. In Culture Crisis: Anthropology and Politics in Aboriginal Australia. Jon Altman and Melinda Hinkson, eds. Pp. 17-31. Sydney: University of New South Wales Press.

PriceWaterhouse Cooper

2007 Living in the Sunburnt Country: Findings of the Review of the Community Housing and Infrastructure Program (CHIP). Canberra: Department of Families, Community Services and Indigenous Affairs.

Rowse, Tim

2010 Re-Figuring "Indigenous Culture.” In Culture Crisis: Anthropology and Politics in Aboriginal Australia. Jon Altman and Melinda Hinkson, eds. Pp. 153-178. Sydney: University of New South Wales Press. 
Simpson, Jane, Jo Caffery, and Patrick McConvell

2009 Gaps in Australia's Indigenous Language Policy: Dismantling Bilingual Education Policy in the Northern Territory. AIATSIS Discussion Paper, 24. Canberra: Australian Institute of Aboriginal and Torres Strait Islander Studies.

Sutton, Peter

2009 The Politics of Suffering: Indigenous Australia and the End of the Liberal Consensus. Melbourne: Melbourne University Press.

Taylor, John

2009 Indigenous Demography and Public Policy in Australia: Population or Peoples? Journal of Population Research 26(2):115130.

Vanstone, Amanda

2005 Beyond Conspicuous Compassion: Indigenous Australians Deserve More Than Good Intentions. Address to the Australia and New Zealand School of Government, Australian National University, Canberra. December 7.

Warner, W. Lloyd

1958 A Black Civilization. Chicago: Harper Row.
Wild, Rex, and Pat Anderson

2007 Ampe Akelyernemane Meke Mekarle "Little Children Are Sacred": Report of the Northern Territory Board of Inquiry into the Protection of Aboriginal Children from Sexual Abuse. 2 vols. Darwin: Northern Territory Government.

Williams, Nancy

1986 The Yolngu and Their Land: A System of Land Tenure and the Fight for Its Recognition. Canberra: Australian Institute of Aboriginal Studies Press.

1987 Two Laws: Managing Disputes in a Contemporary Aboriginal Community. Canberra: Australian Institute of Aboriginal Studies Press.

Yolnguw Makarr Dhuni (Yolngu Nations Assembly)

2012 Statement Regarding Australian Federal Government Stronger Futures Bills and Northern Territory Government Policies, to the Leaders of the Australian Federal and Northern Territory Parliaments. http://concernedaustralians. com.au/media/Stronger_Futures_Statement_Yolngu.pdf, accessed June 15, 2012. 